\title{
Desertification Detected in the Udhaim River Basin, Iraq Based on Spectral Indices Derived from Remote Sensing Images
}

\begin{abstract}
In this study, changes in Land Use Land Cover (LULC) have been investigated over the Udhaim River Basin in Iraq by using spectral indices. NDVI, NDBI, NDWI, NDBal, and Cl represent respectively the vegetation, built-up, water bodies, bare-land, and soil crust of LULC. Two different images were acquired for the analysis, namely a Landsat 5 TM image from 1 July 2007 and a Landsat 8 OLI from 5 June 2015, both representing summer conditions. Results show that the percentages of vegetated land and water body areas have decreased. On the contrary, the percentages of built-up, bare land and soil crust areas have increased. The loss of vegetated areas and water body areas is a signal of land degradation leading to desertification, due to the combined effects of climate conditions, water deficit and human activities. Field observation shows that human activities have a significant impact on land degradation.
\end{abstract}

Keywords

Desertification • GIS • remote sensing • spectral indices • Iraq

(C) University of Warsaw - Faculty of Geography and Regional Studies

\section{Introduction}

Desertification is an important environmental problem. It is a result of land degradation in semi-arid and dry sub-humid areas, which is caused mainly by human activities and climatic variations (Bauer \& Stringer 2009, Sun etal. 2005). Population growth and economic development increase the pressure on land use, especially in vulnerable environments. Unfortunately, most economically developed areas are classified as vulnerable environments (Glenn et al. 1998, Sun et al. 2005). Desertification undermines the land's productivity and contributes to poverty. According to the United Nations Convention to Combat Desertification (UNCCD), desertification is a worldwide phenomenon which affects about $40 \%$ of the Earth's land area (Holtz 2003). Desertification occurs in approximately $70 \%$ of all dry areas. The least developed countries are severely affected by this detrimental process. This includes the territory of Iraq, where it affects $75 \%$ of the total land area, particularly the arable area (Al-Saidi \& Al-Juaiali 2013).

Climatic elements such as rainfall, temperature, sunlight, wind, and human activities such as intensive land use, overgrazing, over-lumbering and logging can lead to changes in land surface conditions during desertification processes (Sivakumar 2007, Zeidler et al. 2002). As a consequence of climate variations and human activities that affect desertification, vegetation conditions in arid, semi-arid and dry sub-humid environments have been greatly changed. These changes include a decrease in vegetation cover, density and biomass, and are also characterized by structural configurations of vegetation types and landscape patterns (Li et al. 2006, Sivakumar 2007, Wu \& Ci 2002)

Vegetation dynamics can also induce changes in soil development, including their physical and chemical properties
Abd Al Salam Mohammed Mail

University of Warsaw, Faculty of Geography and Regional Studies, Poland University of Baghdad, Faculty of Education, Ibn Rushd, Department of Geography, Iraq e-mail: a.mail@student.uw.edu.pl

Received: 15 July 2016

Accepted: 1 March 2017
(Su et al. 2007, Zhao et al. 2006), and the micrometeorological conditions of the land surface, such as temperature, albedo and so on (Gong Li et al. 2000), which are often used to characterize desertification.

The spectral characteristics of desertified land vary greatly, and can thus be captured by satellite sensors. Therefore, satellite images may be fundamental for a quantitative assessment of desertification by means of the indices derived from satellite images (Udelhoven et al. 2003, Lagacherie et al. 2008). Many previous studies have focused on constructing image-based indices to retrieve the vegetation and micrometeorological conditions of the land surface to monitor desertification at different scales (Runnström 2003, Sun et al. 2005).

The number of attempts being made to investigate and measure land-degradation and desertification processes has increased substantially in recent decades. The most effective way to assess and monitor desertification is through employing remote sensing data, such as aerial photography and satellite imagery (Tanser \& Palmer 1999, Seixas 2000, Hostert et al. 2001). The integration of remote sensing with GIS techniques is becoming increasingly important for the assessment of environmental changes to control land desertification (Star et al. 1997, Zhang et al. 2008, Hadeel et al. 2010).

Some indices that can reflect environmental changes are being adopted to assess and monitor desertification, such as the Normalized Difference Vegetation Index (NDVI), which is widely used to assess vegetation conditions (Geerken \& Ilaiwi 2004, Liu et al. 2005), the Normalized Difference Water Index (NDWI), used as a complementary index to the NDVI (McFeeters 1996), 
the Normalized Difference Build-up Index (NDBI), highlighting the urban areas, the Normalized Difference Bare Land Index (NDBal), extracting bare land (Zhao \& Chen 2005), the Crust Index (CI), mapping different lithological units (Karnieli 1997) and the Biological Soil Crust Index (BSCl), mapping different BSC types (Chen et al. 2005).

Landsat series data may provide long-term and high quality multispectral images for environmental monitoring and assessment on regional, national and global scales (Qi \& Cai 2007, Wulder et al. 2008). This paper aims to assess and monitor the environmental changes by developing a modelling method for desertification assessment, which is achieved by using indices from Landsat data. It investigates the temporal and spatial changes of Land Use Land Cover (LULC) and the environmental changes by using remote sensing techniques.

\section{Site Description}

The Udhaim River Basin is one of the most important basins in Iraq. It covers an area of $12,495 \mathrm{~km}^{2}$. It is located entirely within Iraqi territory, between the Little Zab River in the northern part of the basin, the Diyala River to the south, Golan Taslojh and Xuan Skrma Dag to the east and the mountains of Hamrin to the west. It is bounded between latitudes $34^{\circ} 00^{\prime} \mathrm{N}$ and $35^{\circ} 45^{\prime} \mathrm{N}$ and longitudes $43^{\circ} 25^{\prime} \mathrm{E}$ and $45^{\circ} 40^{\prime} \mathrm{E}$. The Udhaim River is one of the main tributaries of the Tigris River, originating from the mountainous regions in northern Iraq and flowing into the Tigris River south of the city of Balad (Fig. 1). The major tributaries of the Udhaim River are Chai Dakuk and Chi-Tuz. Major cities located within the catchment of the Udhaim River Basin are Kirkuk, Chamchamal and Tuz (Fig. 1).

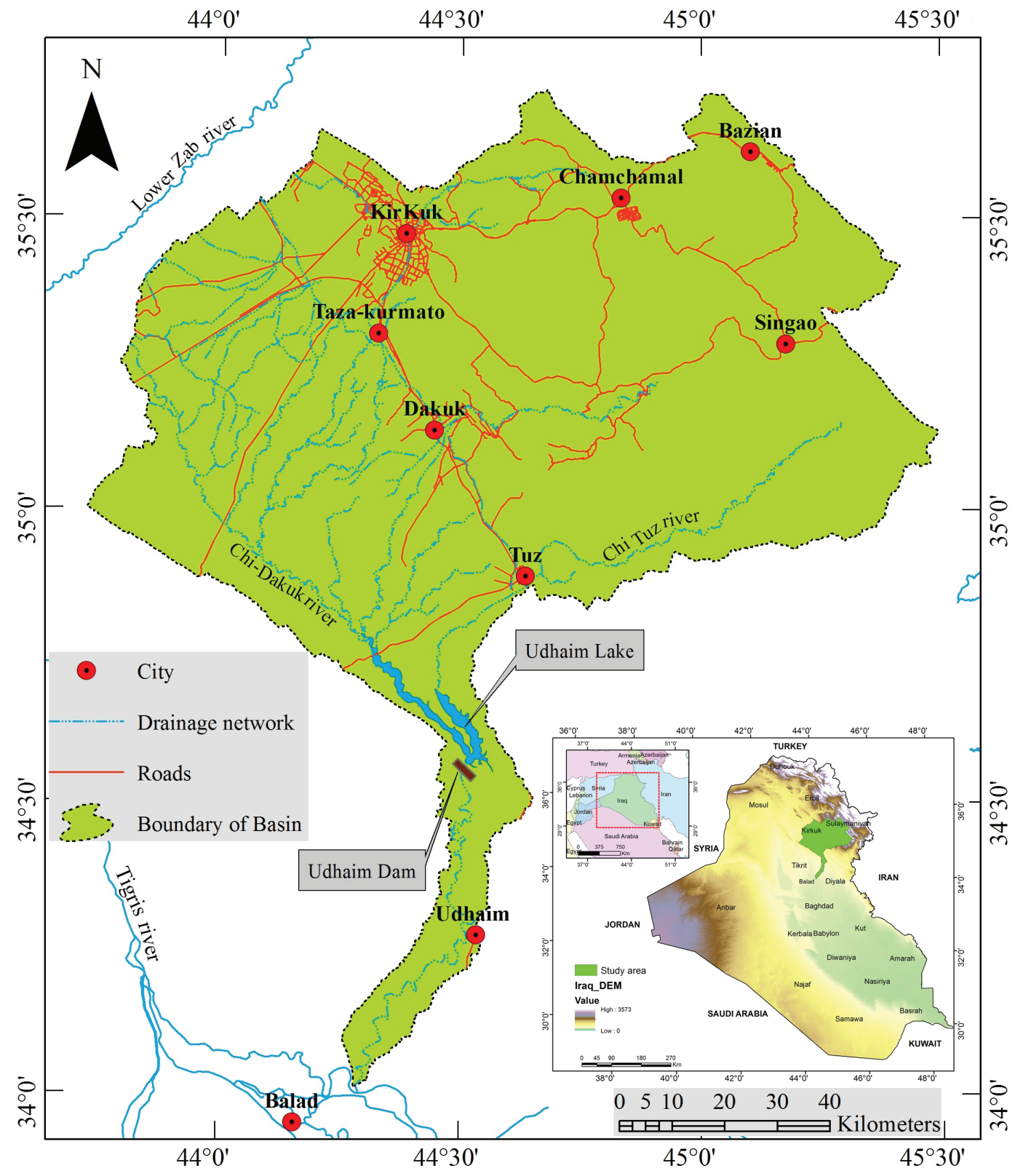

Figure1. Location of Study Area

Source: General Commission of Survey 2013, Iraq Governorates Map, Ministry of Water Resources, Baghdad, Iraq 
The climate of the study area is characterized by an annual precipitation of $270 \mathrm{~mm}$ at Kirkuk station and a mean temperature of $9.2^{\circ} \mathrm{C}$ in winter, increasing to an average of $34.8^{\circ} \mathrm{C}$ in summer.

\section{Data and Methodology}

Multi-band Landsat 5 TM imagery data from 1 July 2007 (2 scenes) and Landsat- 8 OLI imagery data from 5 June 2015 (2 scenes), with $28.5 \mathrm{~m}$ spatial resolution, were obtained (Earthexplorer 2015). The path/row of images describing their positions according to WRS-2 (Worldwide Reference System) are 169/035 and 169/036. Data processing was carried out using ERDAS 2014 and ArcGIS 10.2 software packages (Fig.2). July 2007 and June 2015 represent similar weather conditions, with 6-month SPEI (Standardized Precipitation-Evapotranspiration Index) values of -0.235 and -0.244 respectively, as evaluated for the randomly selected grid point at $35^{\circ} 15^{\prime} \mathrm{N}$ and $44^{\circ} 15^{\prime} \mathrm{E}$, based on the Global Drought Monitor (Vicente-Serrano et al. 2010).

The pre-processing phase began with geometric correction of the images using ground control points, followed by radiometric calibration, atmospheric correction (using ATCOR software), and mosaicking. A small area to the east of the study area was excluded to avoid problems related to the different acquisition date of the Landsat images. The total size of the study area is of $11,169.56 \mathrm{~km}^{2}$.

Based on image processing, five models were designed to extract the spectral indices. The models were processed using ERDAS spatial Modeler Maker. Landsat 5 Thematic Mapper and Landsat $8 \mathrm{OLI}$ data represent the input data for models and the output represents the spectral indices. The Normalized Difference Vegetation Index (NDVI) reflects the state of vegetation growth (Purevdorj et al. 1998) and was calculated as follows:

$$
N D V I=(N I R-R E D) /(N I R+R E D)
$$

Where: NIR is the reflectance of the near-infrared band and RED is the reflectance of the red band.

The Normalized Difference Building Index (NDBI), according to Zha et al. (2003), is sensitive to the built-up area (Zhao and Chen 2005, Chen et al. 2006) and is defined as:

$$
N D B I=(M I R-N I R) /(M I R+N I R)
$$

Where: $M I R$ is the reflectance of the mid-infrared band.

The Normalized Difference Water Index (NDWI) (McFeeters 1996, Chen et al. 2006) is described by the formula:

$N D W I=(N I R-M I R) /(N I R+M I R)$

The Normalized Difference Bareness Index (NDBal) is used to retrieve the bare land area (Zhao and Chen 2005) according to the following:

$N D B a I=(M I R-T I R) /(M I R+T I R)$

Where TIR is the thermal infrared band.

A spectral Crust Index $(\mathrm{Cl})$ is also used in this study and defined as follows (Karnieli 1997):

$C l=1-(R E D-B L U E) /(R E D+B L U E)$

Where: RED - red reflectance, BLUE - blue reflectance. Applying the index to a sand dune environment, it has been shown that the $\mathrm{Cl}$ can be used to detect and map different lithological and morphological units, such as active sands, crusted interlude areas and Playas, from remote sensing imagery (Karnieli 1997). The $\mathrm{Cl}$ image is much more sensitive to the ground features than

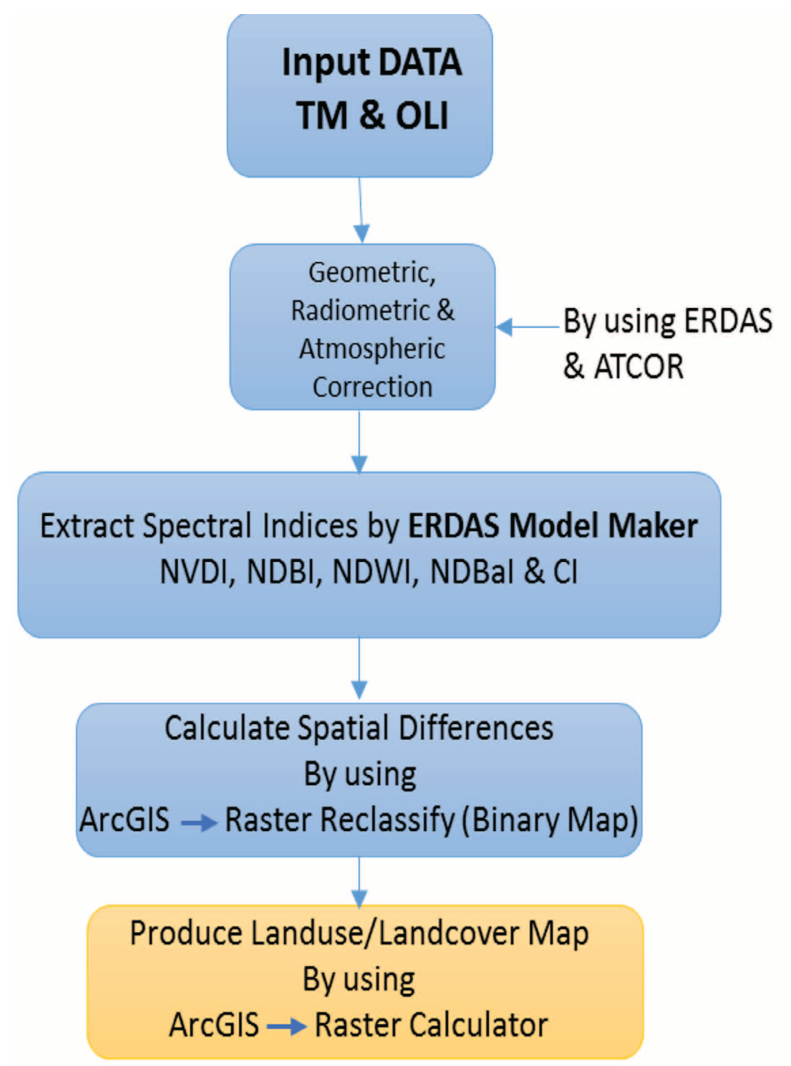

Figure 2. Flowchart of remote sensing data extraction

\begin{tabular}{|c|c|c|c|c|c|c|c|c|c|}
\hline \multicolumn{5}{|c|}{ NDVI Map } & \multicolumn{5}{|c|}{ Binary Map } \\
\hline 0.0 & 0.0 & 0.1 & 0.2 & 0.3 & 0.0 & 0.0 & 0.0 & 0.0 & 0.0 \\
\hline 0.1 & 0.4 & 0.5 & 0.4 & 0.0 & 0.0 & 1.0 & 1.0 & 1.0 & 0.0 \\
\hline 0.2 & 0.4 & 0.6 & 0.7 & 0.0 & 0.0 & 1.0 & 1.0 & 1.0 & 0.0 \\
\hline 0.0 & 0.4 & 0.3 & 0.2 & 0.1 & 0.0 & 1.0 & 0.0 & 0.0 & 0.0 \\
\hline 0.3 & 0.0 & 0.0 & 0.0 & 0.2 & 0.0 & 0.0 & 0.0 & 0.0 & 0.0 \\
\hline
\end{tabular}
Source: Author's elaboration

Figure 3. Converting maps of index ratios to the binary maps (NDVI as an example)

Source: Author's elaboration

the original images (RGB) (Karnieli 1997). The absence, existence and distribution of the soil crust are important information sources for desertification and climate change studies (Karnieli 1997). Chen et al. (2005) introduced the Biological Soil Crust Index (BSCI), but investigations show that it is only suitable for application to cold deserts (Chen et al. 2005). Thus, the BSCl was not considered in this study.

NDVI values range between -1 and 1 . High positive values indicate dense vegetation cover. NDBI and NDBal values are between -1 and 1, like NDVI, and they were used to quantify the amount of the impervious surface and bare land on the used Landsat images, respectively.

After implementing the models in ERDAS software, five binary maps were derived as the results, applying the assumed thresholds. The following thresholds were chosen: NDVI $\geq 0.4$, $\mathrm{NDBI} \geq 0.1$ and NDBI $\leq 0.3$ (As-Syakur et al. 2012), NDWI >0.243 (Xu 2006), NDBal > 0 (As-Syakur et al. 2012, Chen et al. 2006) and $\mathrm{Cl}>0.5$ (Karnieli 1997) (Fig.3). The thresholds vary and differ 


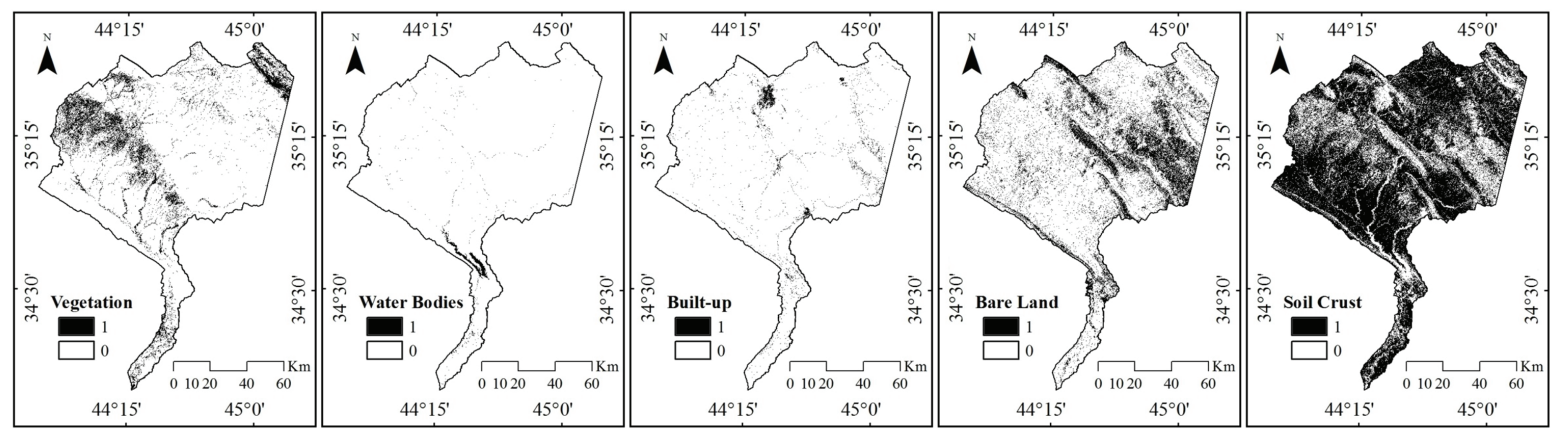

Figure 4. Results of five indices (LULC) derived from Landsat-5 TM 2007

Source: calculated from USGS (2015) Landsat 5 and Landsat 8 Online available Data,http://earthexplorer.usgs.gov/ by using ERDAS Imagine Software
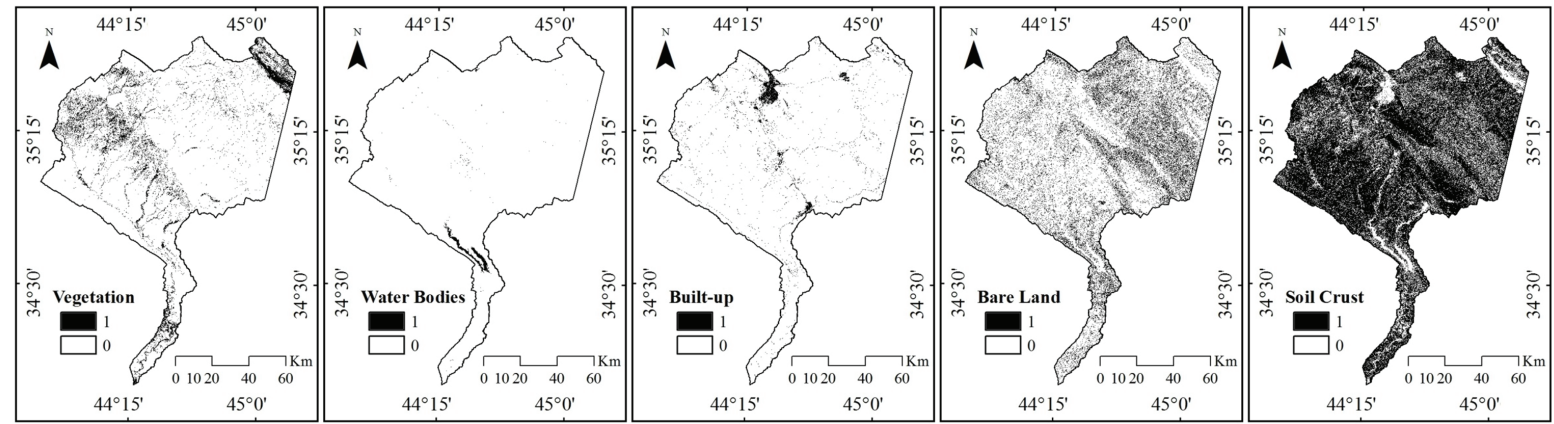

Figure 5. Results of five indices (LULC) derived from Landsat-8 OLI 2015

Source: calculated from USGS (2015) Landsat 5 and Landsat 8 Online available Data,http://earthexplorer.usgs.gov/ by using ERDAS Imagine Software

Table 1. Temporal variation of Land-use/Landcover

\begin{tabular}{|c|c|c|c|c|c|c|c|}
\hline Classes & $\mathbf{2 0 0 7}\left(\mathbf{k m}^{2}\right)$ & $\mathbf{2 0 0 7} \%$ & $\left.\mathbf{2 0 1 5} \mathbf{( k m}^{2}\right)$ & $\mathbf{2 0 1 5} \%$ & Changing area $\left.\mathbf{( k m}^{\mathbf{2}}\right)^{*}$ & Changing *** $^{*}$ & Annual Changing \%*** \\
\hline Soil Crust & $7,414.66$ & 66.38 & $7,749.61$ & 69.38 & 334.95 & 4.52 & 0.65 \\
\hline Bare Land & $2,154.22$ & 19.29 & $2,093.72$ & 18.74 & -60.51 & -2.81 & -0.40 \\
\hline Built-up & 241.43 & 2.16 & 308.30 & 2.76 & 66.87 & 27.70 & 3.96 \\
\hline Water Bodies & 100.14 & 0.90 & 76.51 & 0.68 & -23.63 & -23.60 & -3.37 \\
\hline Vegetation & $1,259.10$ & 11.27 & 941.42 & 8.43 & -317.68 & -25.23 & -3.60 \\
\hline Total & $11,169.56$ & 100.00 & $11,169.56$ & 100.00 & & & \\
\hline
\end{tabular}

- Area $\left(\mathrm{km}^{2}\right)$ of LULC classes in 2007 and 2015 calculated by ArcGIS 10.x (The count of 1 value pixels (cells) multiplied by $900 \mathrm{~m}^{2}$, which is the area of Landsat resolution), changing area $\left(\mathrm{km}^{2}\right)$, changing area (percentage) and annual changing area (percentage) calculated using the formulas below:

${ }^{*}$ Changing area $=$ area of 2015-area of 2007

** Changing $\%=\left(\right.$ Changing area/area of 2007) ${ }^{*} 100$

${ }^{* * *}$ Annual changing $=$ (Changing $\% / 7$-year)

Source:(Fig. 6) by using ArcGIS and Excel Software.

slightly from one region or area to another, according to the subpixel components ( $\mathrm{Ji}$ et al. 2009) and the climatic condition of that area (arid, semi-arid and wet regions) (Choi et al. 2013), so the use of spectral data from the spectral library is required for the adjustment of the threshold according to the case study area.

Each map represents the spatial distribution of the following indices: vegetation area (NDVI), bare land or unused area (NDBal), water area (NDWI), soil crust area $(\mathrm{Cl})$ and built-up area
(NDBI), in the two comparative years $(2007,2015)$ respectively (Fig.4, Fig.5).

ArcGIS software (Raster Calculator) was used to produce a band combination of five indices for each year and one spectral thematic map for visual interpretation and study of the trends in land cover/land use changes. The procedure was based on multiplying each binary map of indices in Fig. 4 and Fig. 5 by the selected number using the Raster Calculator and then adding them to produce a LULC map (Fig.6) 

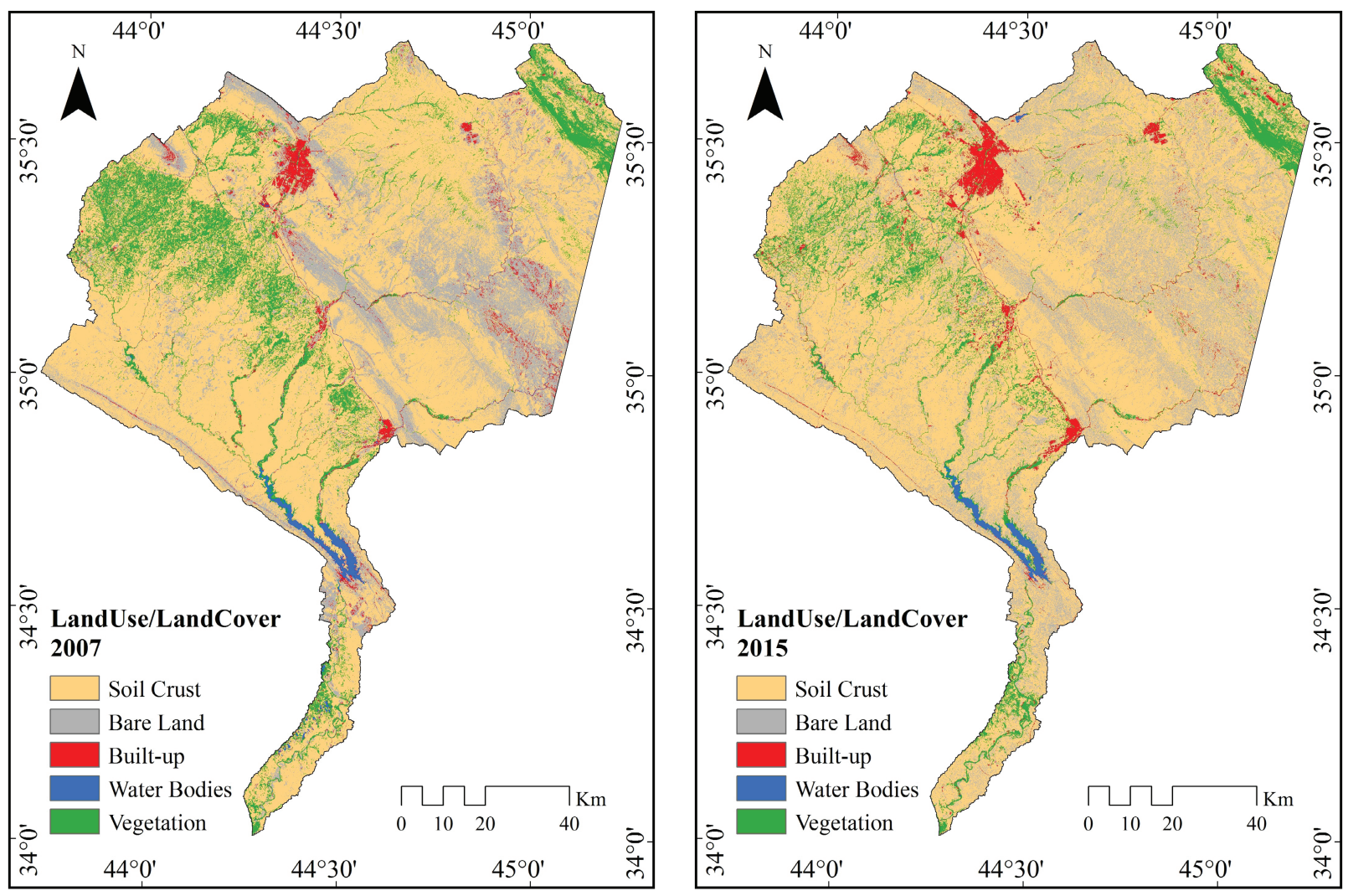

Figure 6. LULC maps generated by a band combination of five spectral indices Source: (Fig. 4 and fig. 5 ) by using ArcGIS software

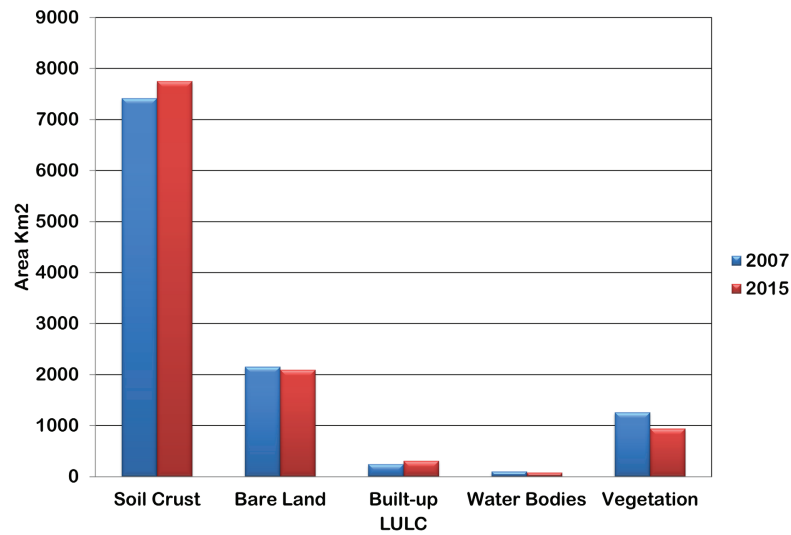

Figure 7. Temporal variations of LULC as estimated by five spectral indices

Source: Table 1

The temporal and spatial changes in the five spectral indices can be distinguished visually (Fig.6). The amount and type of change in each class and in each year can be quantified, as in the table above (Table 1).

\section{Results and discussion}

The percentage of vegetated land area decreased from $11.27 \%$ to $8.43 \%$ between 2007 and 2015 , with an annual rate of change of $-3.6 \%$ of the vegetated area. Water bodies also

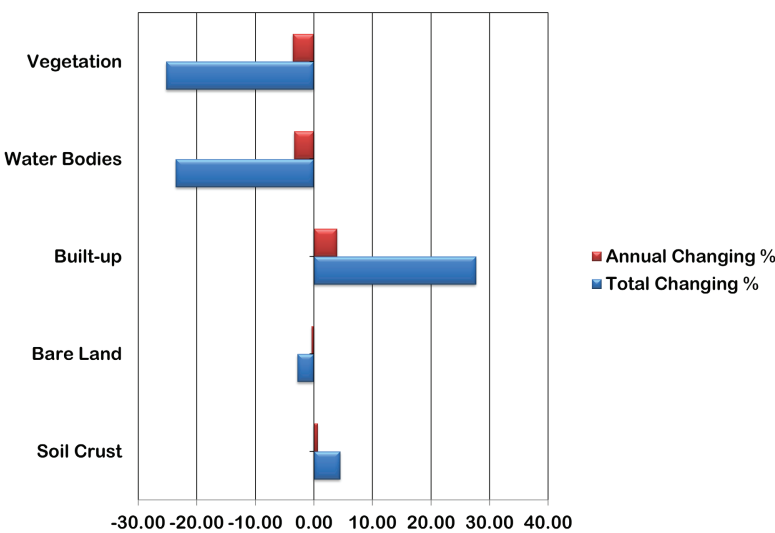

Figure 8. Changes in LULC Source: Table 1

decreased (from $0.9 \%$ to $0.68 \%$ ) between the same years, with a mean annual change of $-3.37 \%$ of the water body areas (Table 1) (Fig. 7 and 8 ). The main water body in the area is still the Udhaim dam reservoir (Pic. $1 \& 2$ ).

The degradation of the vegetated area has obviously been caused by the climatic variations, the deficit in water import, abusive land-use, and the security situation in the area. Since 10 June 2014, most of the villages have been occupied by ISIS and have become battle fields (Pic. 3 ), and most of the people and 


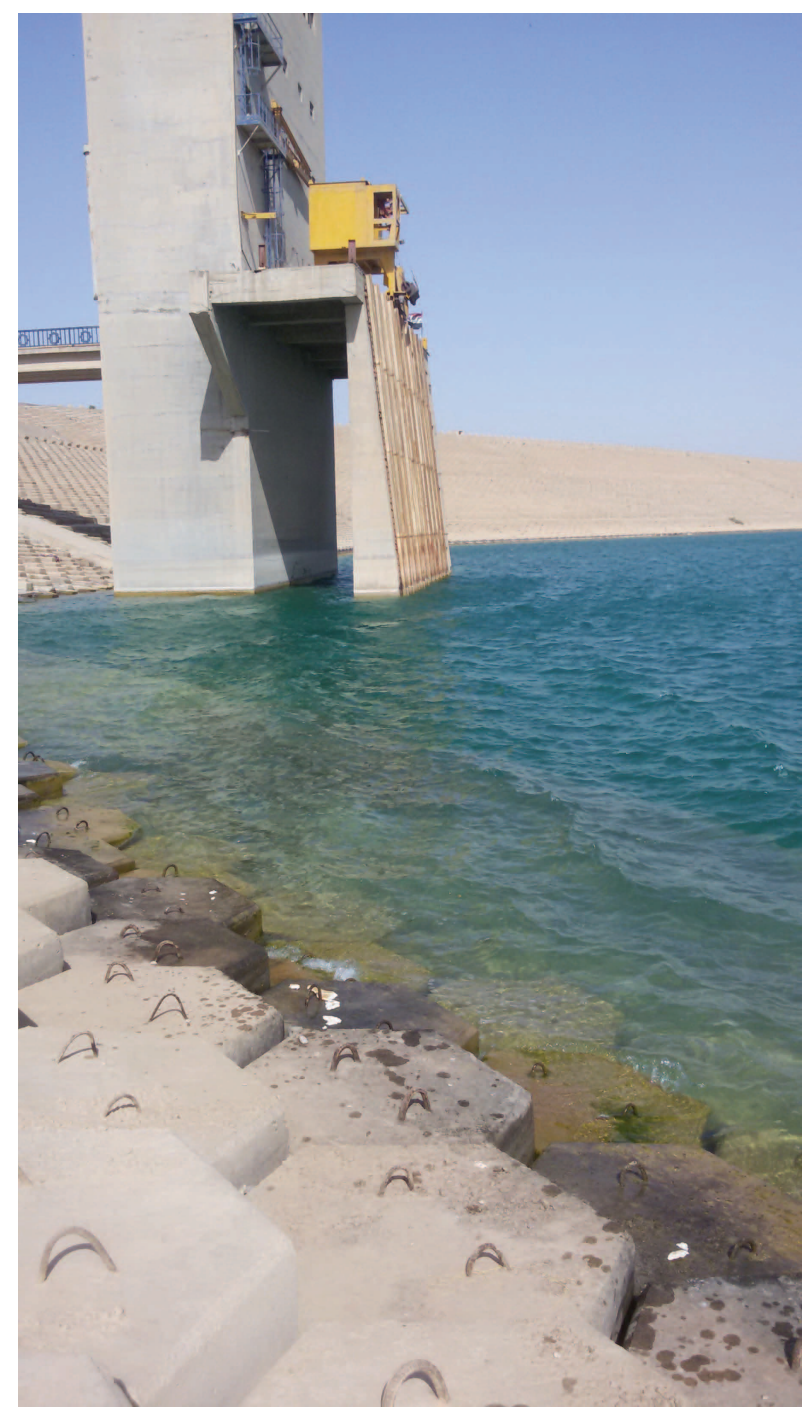

Picture1. The Udhaim dam

Source: Taken by the author on 03.08.2015

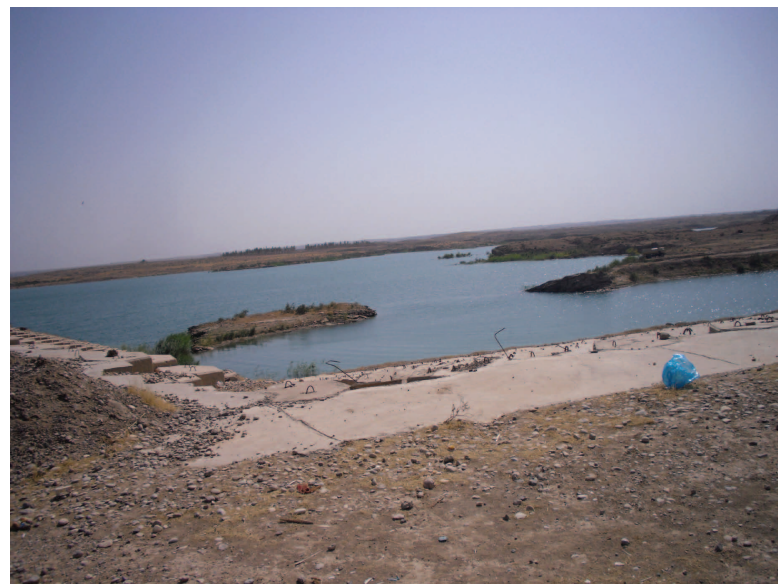

Picture 2. The Udhaim Dam Reservoir

Source: Taken by the author on 03.08.2015

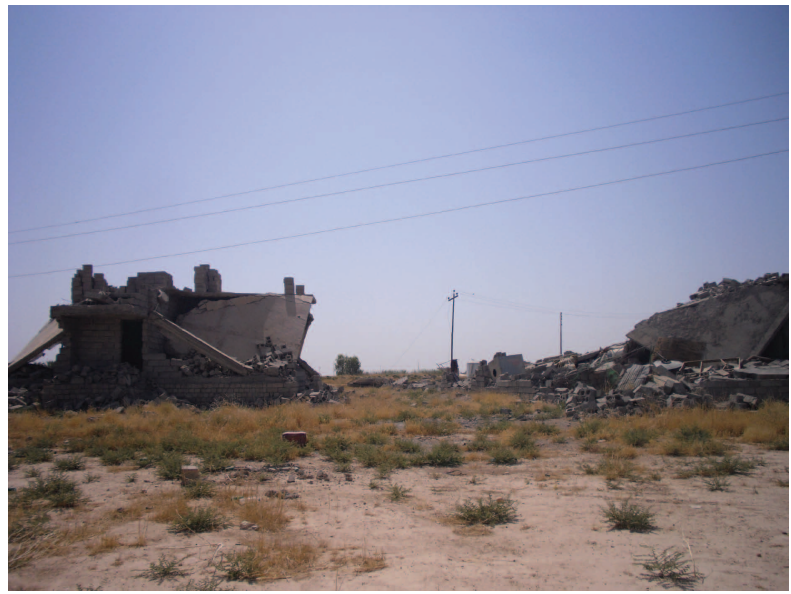

Picture 3. A ruined village following a military operation to liberate it from ISIS

Source: Taken by the author on 03.08.2015

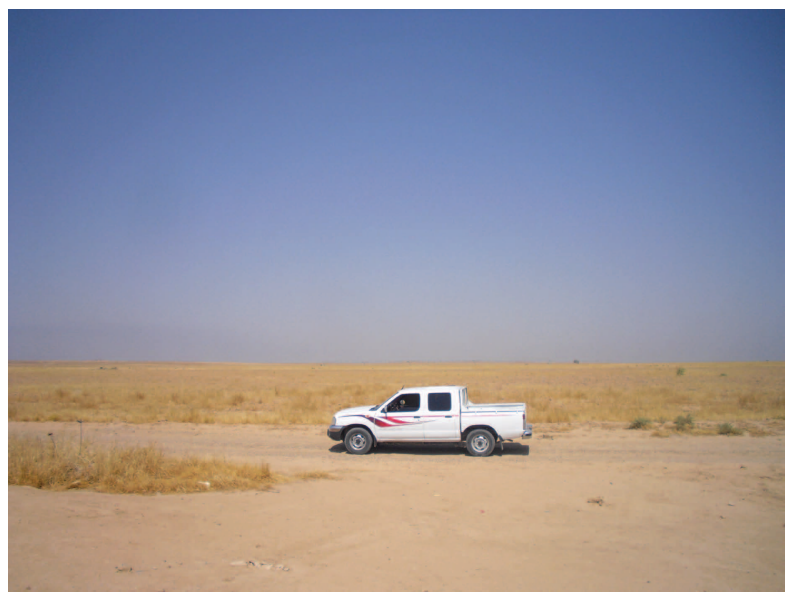

Picture 4. A barley farm abandoned due to forced displacement of farmers

Source: Taken by the author on 03.08.2015

farmers in the villages have fled to Kirkuk, Baghdad and Erbil. All of the farms have been abandoned because of the military activity (Pic.4). Meanwhile, the shrinkage of the Udhaim dam reservoir in the area is due to the decrease in rainfall rates and water received from the valleys.

The growth of the population in the main cities such as Kirkuk and the increase in economic activity have led to a quick expansion of the built-up areas into neighbouring lands. The percentage of urban areas or built-up areas increased from $2.16 \%$ to $2.76 \%$ of the investigated area, with an annual increase rate of $3.96 \%$. It can be determined that the increase in built-up areas between the two comparative years happened more rapidly than the decrease in the vegetation and water body areas (Fig.6 and Fig.7). This shows the strong negative relationship between these types of land use.

The soil crust area is moving in a positive direction, from $66.38 \%$ to $69.38 \%$ of the total investigated area; this is represented by sand dunes and sand sheets (Pic. 5). Conversely, bare land acreage has decreased annually by $-0.40 \%$ of the soil crust area. This sheds light on the retreating of vegetation cover, 


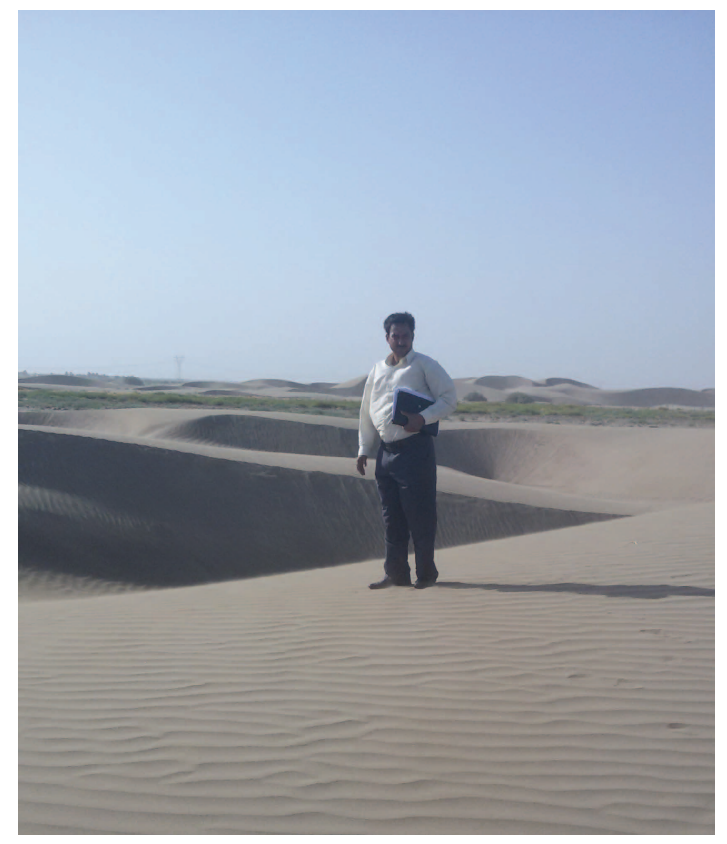

Picture 5. Sand dunes in the study area

Source: Taken by the author on 03.08.2015

water bodies, and even small areas from bare land. This retreat is accompanied by an increase in soil crust and built-up land-use/ land-cover.

This is a clear indication of the effect of desertification processes: climate change and the deficit in imported water have an impact on the vegetation cover and water body areas, and human activities, represented by the expansion of built-up areas, also participate in the degradation of vegetation and water body areas rather than soil crust through their usage for expansion purposes. Currently, the soil crust and built-up areas in the study area represent the degradation of vegetation and water bodies in this territory. This gives a clear sign about the direction of desertification, which is caused mostly by human activities.

\section{Conclusion}

Remotes sensing modelling and GIS techniques are very useful in monitoring and assessing environmental changes and desertification. Desertification in the study area is a natural result of climate change, deep water deficit and human activities. Human activities have had a significant impact on the decrease in vegetation cover. These activities include the bad security situation in Iraq, and especially in the study area, where ISIS occupied the villages and small cities and most of the people (farmers) fled to safe places. The expansion of built-up areas over the degraded lands of vegetation cover and water bodies is another human activity that has had an effect. Theoretically and practically, the degraded lands of vegetation areas and water bodies are best suited to becoming cultivated areas again by using new irrigation methods and precise agriculture techniques in the soil crust lands. The soil crust lands and builtup areas represent the degradation lands of vegetation and the water body areas. The built-up area uses vegetation and bare lands for expansion more than the soil crust areas. This issue requires a reorientation of built-up areas with protection of the degraded lands through adopting a real, effective governmental planning programme. The degraded lands can be cultivated again by using new irrigation methods and precise agriculture techniques.

\section{References}

Al-Saidi, A \& Al-Juaiali, S 2013, 'The economic costs and consequences of desertification in Iraq', Global Journal of Political Science and Administration, vol. 1, no. 1, pp. 40-45.

As-Syakur, AR, Adnyana, I, Arthana, IW \& Nuarsa, IW 2012. 'Enhanced built-up and bareness index (EBBI) for mapping built-up and bare land in an urban area', Remote Sensing, vol. 4, no. 10, pp. 2957-2970.

Bauer, S \& Stringer, LC 2009, 'The role of science in the global governance of desertification', The Journal of Environment \& Development, vol. 18, no. 3, pp. 248-267.

Chen, J, Yuan Zhang, M, Wang, L, Shimazaki, H \& Tamura, M 2005, 'A new index for mapping lichen-dominated biological soil crusts in desert areas', Remote Sensing of Environment, vol. 96, no. 2, pp. 165-175.

Chen, X-L, Zhao, H-M, Li, P-X \& Yin, Z-Y 2006, 'Remote sensing image-based analysis of the relationship between urban heat island and land use/cover changes', Remote Sensing of Environment, vol. 104, no. 2, pp. 133-146.

Choi, M, Jacobs, JM, Anderson, MC \& Bosch, DD 2013, 'Evaluation of drought indices via remotely sensed data with hydrological variables', Journal of Hydrology, vol. 476, pp. 265-273.

Earthexplorer 2015, Landsat Data. Available from: <https:// earthexplorer.usgs.gov/>, U.S.G.S. (United States Geological Survey), USA. Accessed on 21.07.2015

Geerken, R \& llaiwi, M2004, 'Assessment of rangeland degradation and development of a strategy for rehabilitation', Remote Sensing of Environment, vol. 90, no. 4, pp. 490-504.
Glenn, E, Stafford Smith, M \& Squires, V 1998, 'On our failure to control desertification: implications for global change issues, and a research agenda for the future', Environmental Science \& Policy, vol. 1, no. 2, pp. 71-78.

Gong Li, S, Harazono, Y, Oikawa, T, Zhao, HL, Ying He, Z \& Chang, XL 2000, 'Grassland desertification by grazing and the resulting micrometeorological changes in Inner Mongolia', Agricultural and forest meteorology, vol. 102, no. 2, pp. 125-137.

Hadeel, AS, Jabbar, MT \& Chen, X 2010, 'Environmental change monitoring in the arid and semi-arid regions: a case study Al-Basrah Province, Iraq', Environ Monit Assess, vol. 167, no. 1-4, pp. 371-85.

Holtz, U 2003, 'The United Nations Convention to Combat Desertification (UNCCD) and its Political Dimension'. Contemporary German Arts And Letters, 1-11. www.unccd.int/Lists/SiteDocumentLibrary/Parliament/2003/ PDUNCCD(eng).pdf Accessed on 20.07.2015.

Hostert, P, Roder, A, Jarmer, T, Udelhoven, T \& Hill, J 2001, 'The potential of remote sensing and GIS for desertification monitoring and assessment', Annals of Arid Zone, vol. 40, no. 2, pp. 103-140.

Ji, L, Zhang, L \& Wylie, B 2009, 'Analysis of dynamic thresholds for the normalized difference water index', Photogrammetric Engineering \& Remote Sensing, vol. 75, no. 11, pp. $1307-1317$.

Karnieli, A 1997, 'Development and implementation of spectral crust index over dune sands', International Journal of Remote Sensing, vol. 18, no. 6, pp. 1207-1220. 
Lagacherie, P, Baret, F, Feret, JB, Madeira Netto, J \& RobbezMasson, JM 2008, 'Estimation of soil clay and calcium carbonate using laboratory, field and airborne hyperspectral measurements', Remote Sensing of Environment, vol. 112, no. 3 , pp. 825-835.

Li, X, Jia, X \& Dong, G 2006, 'Influence of desertification on vegetation pattern variations in the cold semi-arid grasslands of Qinghai-Tibet Plateau, North-west China', Journal of Arid Environments, vol. 64, no. 3, pp. 505-522.

Liu, A, Wang, J \& Liu, Z 2005, 'Monitoring desertification in arid and semi-arid areas of China with NOAA-AVHRR and MODIS data', Geoscience and Remote Sensing Symposium, 2005. IGARSS'05. Proceedings. 2005 IEEE International, 2005. IEEE, pp. 2362-2364.

Mcfeeters, S 1996, 'The use of the Normalized Difference Water Index (NDWI) in the delineation of open water features', International Journal of Remote Sensing, vol. 17, no. 7, pp. 1425-1432.

Purevdorj, T, Tateishi, R, Ishiyama, T \& Honda, Y 1998, 'Relationships between percent vegetation cover and vegetation indices', International Journal of Remote Sensing, vol. 19 , no. 18 , pp. 3519-3535.

Qi, S \& Cai, Y 2007, 'Mapping and assessment of degraded land in the Heihe River basin, arid northwestern China', Sensors, vol. 7, no. 11, pp. 2565-2578.

Runnström, M 2003, 'Rangeland development of the Mu Us Sandy Land in semiarid China: an analysis using Landsat and NOAA remote sensing data', Land Degradation \& Development, vol. 14, no. 2, pp. 189-202.

Seixas, J 2000, 'Assessing heterogeneity from remote sensing images: the case of desertification in southern Portugal', International Journal of Remote Sensing, vol. 21, no. 13-14, pp. 2645-2663.

Sivakumar, M 2007, 'Interactions between climate and desertification', Agricultural and forest meteorology, vol. 142, no. 2, pp. 143-155.

Star, JL, Estes, JE \& Mcgwire, KC 1997, Integration of geographic information systems and remote sensing, New York, Cambridge University Press.

Su, YZ, Zhao, WZ, Su, PX, Zhang, ZH, Wang, T \& Ram, R 2007, 'Ecological effects of desertification control and desertified land reclamation in an oasis-desert ecotone in an arid region: a case study in Hexi Corridor, northwest China', Ecological Engineering, vol. 29, no. 2, pp. 117-124.

Sun, D, Dawson, R, Li, H \& Li, B 2005, 'Modeling desertification change in Minqin county, China', Environ Monit Assess, vol. 108, no. 1, pp. 169-188.
Tanser, FC \& Palmer, AR 1999, 'The application of a remotelysensed diversity index to monitor degradation patterns in a semi-arid, heterogeneous, South African landscape', Journal of Arid Environments, vol. 43, no. 4, pp. 477-484.

Udelhoven, T, Emmerling, C \& Jarmer, T 2003, 'Quantitative analysis of soil chemical properties with diffuse reflectance spectrometry and partial least-square regression: A feasibility study', Plant and Soil, vol. 251, no. 2, pp. 319-329.

Vicente-Serrano, SM, Beguería, S \& López-Moreno, JI 2010, 'A multiscalar drought index sensitive to global warming: the standardized precipitation evapotranspiration index', Journal of Climate, vol. 23, no. 7, pp. 1696-1718.

Wu, B \& Ci, LJ 2002, 'Landscape change and desertification development in the Mu Us Sandland, Northern China', Journal of Arid Environments, vol. 50, no. 3, pp. 429-444.

Wulder, MA, White, JC, Goward, SN, Masek, JG, Irons, JR, Herold, M, Cohen, WB, Loveland, TR \& Woodcock, CE 2008, 'Landsat continuity: Issues and opportunities for land cover monitoring', Remote Sensing of Environment, vol. 112 , no. 3, pp. 955-969.

$\mathrm{Xu}, \mathrm{H}$ 2006. 'Modification of normalised difference water index (NDWI) to enhance open water features in remotely sensed imagery', International Journal of Remote Sensing, vol. 27, no. 14 , pp. 3025-3033.

Zeidler, J, Hanrahan, S \& Scholes, M 2002, 'Land-use intensity affects range condition in arid to semi-arid Namibia', Journal of Arid Environments, vol. 52, no. 3, pp. 389-403.

Zha, Y, Gao, J \& Ni, S 2003. 'Use of normalized difference builtup index in automatically mapping urban areas from TM imagery', International Journal of Remote Sensing, vol. 24, no. 3, pp. 583-594.

Zhang, Y, Chen, Z, Zhu, B, Luo, X, Guan, Y, Guo, S \& Nie, Y 2008 , 'Land desertification monitoring and assessment in Yulin of Northwest China using remote sensing and geographic information systems (GIS)', Environ Monit Assess, vol. 147, no. 1 , pp. 327-337.

Zhao, H \& Chen, X 2005, 'Use of normalized difference bareness index in quickly mapping bare areas from TM/ETM+', Geoscience and Remote Sensing Symposium, 2005. IGARSS'05. Proceedings. 2005 IEEE International, 2005. IEEE, pp. 1666-1668.

Zhao, HL, Zhou, RL, Zhang, TH \& Zhao, XY 2006, 'Effects of desertification on soil and crop growth properties in Horqin sandy cropland of Inner Mongolia, north China', Soil and Tillage Research, vol. 87, no. 2, pp. 175-185. 